(Cumberland, West Indian, II, 2). - A penny to the side that finds the most (Pett Ridge, Sanderson, T, 21). - Those who shout the loudest do not always obtain the most (Times W. Ed., 22, 3, 1912). - Where the early heather grew in tufts of deepest blue (Dell, Knave of Diamonds, 216. To what does Honour devote the most of his attention? (The King and Isabel, 154).

$\S 7$. The same phenomenon as with predicative and adverbial superlatives is seen with superlatives preceded by $a t$ : In such eminently rhythmical prose as Liddon's translation of Thomas à Kempis' Imitatio Christi, there is an undeniable striving after melody in such sentences as:

Some meet their heaviest trials at the first

Along the pathway of their road to God

and

So every fleshly joy comes with a smiling face,

But at the last it bites and kills.

(20 Febr.)

And I feel convinced that in these cases the article was inserted for rhythmical purposes. Yet, it is a device that is rarely resorted to by prosewriters. Poutsma (Grammar, II, 498) is quite right in stating that after "at" the article is commonly suppressed before a superlative.

Utrecht.

P. Fijn Van Draat.

\title{
IS THERE SUFFICIENT EVIDENCE TO WARRANT THE AUTHENTICITY OF OE. TREPPAN 'TO TRAP'?
}

The NED sub Trap $\mathbf{v}^{1}$ prints as first quotation of this verb in its transitive sense, on the authority of Bosworth-Toller, the Kentish gloss $211 \mathrm{Hio}$ [tr]e[p]te inretivit, though including it in brackets. Now it is true that Zupitza who first edited the Kentish glosses on the book of Proverbs from MS. Cott. Vesp. D 6, in vol. IX of Zeitschrift für deutsches Alterthum, thus supplied the missing letters, the manuscript exhibiting hio .e.te as explanation of inretiuit. It is also true that Wülcker, incorporating these glosses in his revised edition of Wright's Vocabularies, accepted in his foot-note to WW. I. 6125 Zupitza's conjecture as to the meaning of the dots. However, Zupitza himself had qualified his conjecture by a 'perhaps' and a query and' so very prudently $\mathrm{Hall}$ in the first edition of his Concise Anglo-Saxon Dictionary booked treppan ' $w v$. to trap, ensnare' with a query, too, giving as his source 'K[entish] Gl[osses published in Wright-Wülcker I.] 6125. It is to be regretted that he dropped this prudence in the revised edition of his Dictionary. For on page 301, column a, of this work we find treppan I. to 'trap'. KGL., as though the authenticity of the word were unquestionable. It is, however, just as much of a question now as it was to Zupitza himself whether or not he correctly supposed hio .e.te was meant for hio trepte. He had no doubt in mind the passage from the Chronicles of the year 992 (Canterbury MS.): And her gercedde se cing 7 ealle his witan $p$ man gegaderode ealle ða scipa pe ahtes waran to Lundenbyri, to dan $p$ man' scolde' fandiam. 
gif man mihte be troeppan ${ }^{1)}$ pane here ahwar wip utan. But is it likely the glossator meant to indicate trepte, when the number of dots employed is just sufficient for repte? In fact, if it could be shown that OE. rápan was used in the sense of modern 'to rope in' or 'to entangle in the ropes (sc. of the net'), I would strongly recommend hio [r]e[p]te as the most plausible reading of the hio .e.te 'inretiuit' on record in the gloss on the Proverbs. However, the word is, on the one hand, rarely met with and, on the other, seems to mean only 'to fasten, to bind with a rope'. I know only of the two instances B.-T. quotes for the simplex from the Chronicles ad annum 1011: ure earme folc rapton and slogan and mid racentan rapan from the Metres of Boethius 26, 78.

For the compound gerápan B.-T. has six examples from the same source, but notes only 'to bind' as meaning. Still, as there is a noun netrap 'plaga, bolis' recorded (WW. $\left.16712 ; 183^{9} ; 19511\right) 2$ ), it is conceivable that rápan, gerópan might have been used in the sense of genettian 'inretire'.

OE. (Northumbrian) óht-rip : OHG. âhtsnit 'messis dominica'.

Clark Hall books in the first edition of his Concise Anglo-Saxon Dictionary on page 234, column a, with a query ohtrip sn. 'harvest'. In the second edition, on page 223 , column a, he has substituted for this the entry (also with a query) ofetrip $\mathrm{n}$. 'harvest' and refers the reader to Zeitschrift für deutsche Philologie 36, 550. The query is well justified. For what Binz, at the place indicated, brings forward in support of his conjecture that the ohtrip twice recorded in the Lindisfarne Gospels (Matthew 9, 31 and Luke 10,2 ) stands for ofetrip is, to be sure, ingenious, but not convincing, and Hall would have done better booking the word as it is recorded and referring to Binz's conjecture in ZDPh. 36,550 as a commendable alteration, if it so appeared to him, at the same time marking the word as Northumbrian. I believe I can show there is no need for the alteration proposed by Binz. All we have to do to make ohtrip understandable as a rendering of messis in the Matthew and Luke passages pointed out above is to mark 0 as long, since the word is a compound of the well-known óht $=$ OHG. aht 'per-

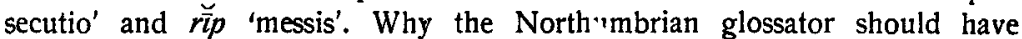
thought fit to render Latin messis here by the compound ótrip 'forced (work in the) harvest(-field)', a glance at the whole passage will teach us: "Pray ye therefore the Lord of the harvest (dominum messis), that he will send forth labourers into his harvest." The picture of God as the Lord of the harvest portrayed here forcibly reminded the Old English interpreter of the Lord of the Manor who has at his command (bén or bed) an army of

1) Laud MS. betrappen.

2) Hall in the 2nd edition of his Dictionary adds an instance from Flfric's LL SS 3178 in the sense of 'yoke together'. The geraptan 'bind, fetter' he books from Boethius ed. Sedgefield 1121 I have on my list of proscribenda, but unfortunately I am unable here to verify the proscription. 
reapers to perform the needful work in his harvest-field (benrip or bedrip). Because he can enforce his demand for such work in the harvest-field, the glossator more pregnantly calls it óht-rip. In the heading of this article I draw attention to the corresponding expression âhtsnit in Old High German, for confirmation of which I may be permitted to quote the following from page 20 of Wackernagel's edition of Das Bischofs- und Dienstmannenrecht von Basel, Basel 1852. The date of this document written, according to Wackernagel, by a man hailing from the Lower Rhine is after the year 1250 and before 1262. Paragraph 15 of it reads thus: Dis Sint Diu Recht ze Basil, alle die hovestete zinsent dem bischof ze Saint Martins mis, die ganze hovestat, die verzich vïeze wit ist, vier phenninge, die halbe zwene. Swer daz versizzet, morindis driu phunt. Der tuomherren, der amtliuten unde der gotshus dienstman hiuser gat daz an niut. pfaffen unde ambtliute hiuser, da si inne sizzent, gebent niht. Ouch erteilet man dem bischove von ieclicheme hus der burger ein ahtsniter, unde sol man der ieclicheme geben des nahets ein brot, unde sprichet man in dar nach in den vierzen nahten an, daz er da niht si gewesin, das sol er bereden mit dem brote, unde bedarf andere geziugen niht, so die verzen naht hin sint, so inmach man in nümme an sprechen. Swer ouch den ahtsniter nüt git, der büezet driu phunt.

Very instructive is what in his notes to this paragraph Wackernagel says on page 41 in explanation of âhtsniter occurring twice: "âhte ist ausgesondertes Ackerland des Herren, das von den Hörigen bestellt und abgeerndtet, und die Dienstbarkeit selbst, die auf einem solchen gethan wird. Das Wort kommt besonders häufig in Trierischen Weisthümern (DWB von Jacob und Wilhelm Grimm I, 165), aber auch sonst vor: achtpferd, achtschnieder, Weisthümer 2, 179. Die Länge des a beweisen die Schreibung und die Aussprache aacht, Weisthümer 2, 266, ochtschnitter 151, Die Zusammensetzung âchtwort dagegen, in welcher wort 1) so viel als Umhegung ist (DWB I, 172), bezeichnet einen als Forst oder Weide ausgesonderten Wald oder Waldtheil und das Recht zu dessen Nutzung (Scheidts Mantissa Documentorum 364, Haltaus 251). Beidesmal bedroht der Name den, welcher an der Frucht oder am Holze freveln würde, mit der æhte oder âthe, mit gerichtlicher Verfolgung.

As to what sort of people were bound to perform this enforced labor in the harvest-field we learn from what Wackernagel quotes in explanation of des nahtes ein brot from the Recht von Maursmünster: Ea die, quando secari debet, omnes qui in hac marcha sunt, qui vires ad secandum habent, adesse debent. - Abbas autem unicuique secantium dare debet panem honestum, altero anno carnes, altero caseum et iterum altero vinum, altero cerevisiam. - Cum vero secatum fuerit, omnis qui domum in hac marcha

1) This perhaps corresponds to OE. worp (with the by-forms worpig and worpign). The meaning 'Umhegung' in the German acht-wort may have developed from that of 'Umdämmung'. At any rate, the OE. worb seems to have meant originally a dam, an elevation of the ground either naturally caused e. $g$. by the earthy deposits of a river or the sea, or artificially cast up for protection by human hands. I expect to deal more fully with this word in a special article. 
habuerit, unum hominem ${ }^{1}$ ), qui fenum parent ${ }^{1}$ ), mittere debet (Schöpflin 1, 125). Cuncti quoque per eandem marcham constituti abbati quatuor jugera arare debent 2 ), tres in autumno, unum in vere, tali modo ut sibi ipsis - abbas autern unicuique aratro tres panes dare debet, ad tria jugera cerevisiam, ad quartum vinum. Similiter omnes, qui in marcha sunt, unum messorem ad recolligendas fruges abbati mittere debent, unum ad hiemales fruges et unum ad cestivales. - Iisdem vero messoribus bis dari debet ad manducandum et unus panis qui dicitur ahtebroth (ebenda 226). Lakeland, Fla.

OTTO BERNHARD SCHLUTTER.

\section{A NOTE ON THE NEOPHILOLOGUS, 1919, pp. 88-96.}

On Dr. Pompen's review of my Studies in Milton I should like to make the following observations:

I am sorry that the fatal misprint on p. 82 "March 16, 1649" has escaped my attention. P. 42, 1. 12 from below is the year correctly given as 1648-9. I have turned up the entry in the printed copy in the British Museum as well as in the original, written registers at Stationers' Hall, where it occurs in due place in the part recording the entries of 1649 . There can be no doubt about that.

I regret very much not to be able to furnish any further information about the supposed Simmons's copy. While in London I wrote to Mr. Almack asking his assistance, but I never got an answer. Nevertheless I hardly think this edition necessary as a conclusive evidence. The revolutionaries may have decided to let Simmons print an edition for them, to mix up with the others, but, on catching Dugard and his ready printed fifth and sixth impressions and obliging him to publish them with the prayerappendix, they may have lost interest in Simmons's edition. To me the conclusive proofs are to be found in the minutes of the committee referred to on p. 43 in my book. I made every effort to get these minutes but they were supposed to be somewhere in the Parliament House and I tried in vain to be admitted there.

My reproducing the sources word by word to an unusually great extent seems to Dr. Pompen faulty method but is nevertheless done on purpose. The sensational nature of the subject put the author in a very difficult and delicate position; it asked for a treatment which would afford the scholar and the serious reader access to every important document known to me. I wanted, in a manner, to make my statements superfluous to the reader; I wanted him to make the investigation for himself, free from the weary hunting up of the original pieces of evidence. Moreover, in an exposition like this one, which so much approaches, or rather is, a piece of a history of civilization, regard is to be had in the first place to the atmosphere of

1) I cannot vouch here for the correctness of my copying from Wackernagel's print. It would seem that we have to read either unum hominum, qui fenum parent, or unum hominem, qui fenum paret.

2) Compare OE. bén-yrp. 